\title{
PERAN PEKERJA SOSIAL DALAM PEMBENTUKAN KONSEP DIRI POSITIF BAGI LESBIAN DI KOTA TASIK
}

\author{
Oleh: \\ Shella Adelina, Binahayati, \& Meilanny Budiarti S. \\ E-mail: \\ shellaadelina@yahoo.com
}

\begin{abstract}
ABSTRAK
Fenomena homoseksual telah menjadi trend di kehidupan masyarakat Indonesia. Tidak hanya di kota-kota besar, di kota-kota kecil yang sarat akan norma dan budaya pun homoseksual menjadi permasalahan yang sulit dikendalikan. Bukan hanya mengenai aspek moral, homoseksual dipengaruhi pula oleh gaya hidup dan hubungan sosial. Hal ini telah menjadi perhatian yang serius bagi pemeritah Kota Tasik karena homoseksual dianggap masalah sosial yang mencoreng nama baik Kota Tasik sebagai Kota Santri. Bagi lesbian, menunjukkan dirinya sebagai penyuka sesama jenis adalah hal yang sulit. Terlebih posisi perempuan di Indonesia sangat sentral dan terikat pada nilai dan norma-norma sosial. Kesulitan membuka diri menjerumuskan lesbian untuk bergabung kedalam komunitas lesbian agar memperoleh penerimaan diri dan rasa aman. Konsep diri lesbian cenderung negatif karena terdapat faktor labeling dan penolakan yang diterima lesbian dari lingkungan sekitarnya. Masyarakat lebih senang "mengobati" lesbian daripada "merubah perilaku" padahal lesbian bukanlah penyakit, melainkan perilaku seksual menyimpang. Pemerintah telah memiliki kebijakan yang mengenai larangan menjadi homoseksual. Namun diperlukan dukungan lain dari berbagai pihak terkait dan para profesional untuk mengatasi permasalahan lesbian. Pekerja sosial adalah profesi profesional pemberi bantuan yang berfokus pada keberfungsian sosial dengan memperhatikan aspek orang didalam lingkungan. Pekerja sosial dapat berperan dalam mengatasi permasalahan individu dan lingkungan. Hasil penelitian ini mengungkapkan : Keberadaan lesbian di Kota Tasik cenderung meningkat setiap tahun; belum ada program yang tepat bagi penanganan lesbian; belum adanya peran pekerja sosial dalam upaya penanganan lesbian di Kota Tasik.
\end{abstract}

Kata kunci : peran pekerja sosial, lesbian, perubahan perilaku

\section{ABSTRACT}

The phenomenon of homosexuality has become a trend in Indonesian society. It has become a serious concern for Government because of homosexual is considered a social problem. For lesbian, showed herself is a difficult thing. Moreover, the position of women in Indonesia is very central and tied to the values and social norms. Difficulty opening themselves plunged into a lesbian to join the lesbian community in order to gain acceptance and sense of security. The self concept tend to be negative because there are factors labeling and lesbian rejection received from the surrounding environment. People are much more pleased "cure" lesbian rather than "change behavior" while lesbian is not a disease, but a deviant sexual behavior. However, other support needed from various stakeholders 
and professionals to overcome the problems. Social workers can play a role in overcoming the problems of individuals and the environment that focuses on social functioning by taking into account those aspects in the environment. RESULTS: The presence of lesbians in Tasik City tends to increase every year; there has been no proper program for handling lesbian; the absence of social worker's role in efforts to address lesbian.

Keywords : role of social workers, lesbian, change behavior

\section{PENDAHULUAN}

Fenomena homoseksual telah menjadi trend di kehidupan masyarakat Indonesia. Hasil survei YPKN menunjukkan, ada 4.000 hingga 5.000 penyuka sesama jenis di Jakarta. Sedangkan Gaya Nusantara memperkirakan, 260.000 dari enam juta penduduk Jawa Timur adalah homoseksual. Komisi Pemerhati Anak dan Remaja (KPAR) Tasikmalaya, jumlah warga terindikasi suka sesama jenis tahun 2014 adalah 1.578 orang. Jumlah ini naik 300 orang dari tahun 2013, dan golongan ini tersebar di 69 kelurahan wilayah Kota Tasikmalaya. Menurut catatan LSM Abiasa dan Komisi Penanggulangan AIDS Jawa Barat, di Jawa Barat jumlah kaum gay diperkirakan mencapai 6000 orang, dan di kota Bandung tidak kurang dari 656 orang tercatat sebagai homoseksual (Saputri, 2011). Di Indonesia sendiri terdapat beberapa contoh orang-orang yang berani mempublikasikan dirinya gay dikhalayak umum seperti Oetomo yang merupakan presiden gay di Indonesia, dan Jupiter Fourtissimo merupakan seorang aktor yang membuat pernyataan langsung diacara Silet, 24 Januari 2008 (Laily Andini dalam Kompasiana, 2013).

Homoseksual menjadi fenomena global yang permisif bagi masyarakat. Pengaruh globalisasi dalam konteks revolusi teknologi informasi dan komunikasi, berimplikasi pada keterbukaan penyebaran ideologi homoseksual untuk semakin dipandang "ada" oleh masyarakat. Berdasarkan hasil survey Oetomo memperkirakan secara nasional, terdapat $1 \%$ jumlah komunitas homoseksual di Indonesia.
Sedangkan jumlah lesbian dan komunitasnya belum terdata karena komunitasnya lebih eksklusif. Beberapa contoh komunitas homoseksual di Indonesia diantaranya, Gaya Nusantara, Gaya Pride Indonesia, Arus Pelangi, Komunitas Swara Srikandi, Gaya Priangan dan Himpunan Abiasa.

Apabila dilihat dari sisi sosial, homoseksualitas dipandang sebagai masalah sosial dengan kategori perilaku menyimpang yang disebabkan oleh perubahan sosial (seperti yang diungkapkan Merton dan Nisbet dalam Budi Wibhawa, 2010). Masalah sosial yang berasal dari perubahan sosial merupakan perluasan dari masalah sosial-ekonomi kepada masalah sosial-psikologis. Hal ini berkaitan dengan nilai-nilai dan norma-norma sosial budaya masyarakat itu sendiri. Homoseksual sebetulnya tidak termasuk kedalam gangguan jiwa/penyakit sejak tahun 1993 (dalam Pedoman Penggolongan dan Diagnosis Gangguan Jiwa III, disusun oleh Direktorat Kesehatan Jiwa, Dep-Kes RI). Jika ada yang menderita gangguan jiwa karena homoseksualitas, maka itu disebabkan dari chain effect permasalahan sosial yang ditimbulkan oleh perilaku homoseksual.

Menurut survey yang dilakukan PEW Research Global Attitudes Project yan dirilis tanggal 4 Juni 2013 mengenai penerimaan kelompok homoseksual di dunia, Indonesia menempati urutan ke-7 dari 10 dengan presentase $3 \%$. Sementara diantara seluruh negara yang memiliki penduduk muslim terbanyak, Indonesia menempati urutan ke-5 dengan $93 \%$ dalam penolakannya terhadap homoseksualitas. Artinya, permasalahan 
homoseksual masih kontradiktif di kalangan masyarakat Indonesia, terutama lesbian. Oleh karena itu, lesbian dianggap kaum marginal di dalam lingkungan masyarakat Indonesia yang memang melarang keras, mengucilkan, dan menghukum para homoseksual.

Lesbian adalah adalah istilah perempuan yang mengarahkan orientasi seksualnya kepada sesama perempuan atau disebut juga perempuan yang mencintai perempuan baik secara fisik, seksual, emosional atau secara spiritual. (Adhiati dalam Ary Trisna, $2010: 3$ ).

Penerimaan yang rendah atas identitas diri abu-abu yang dimiliki lesbian dapat menjadi pendorong konsep diri negatif yang dapat berdampak lanjut pada gangguan kejiwaan. Terlebih posisi perempuan di Indonesia masih dipandang rendah oleh masyarakat. Konsep diri negatif yang diterima lesbian dapat berasal dari labelling yang diberikan masyarakat. Anggapan bahwa lesbian adalah penyakit kotor menjadi asumsi yang sering disuarakan.

Lesbian adalah kelompok yang rentan masalah sosial karena penerimaan diri yang rendah dan sanksi sosial masyarakat mengikuti kehidupan mereka. Hal ini tidak mungkin membawa penilaian negatif pada diri lesbian sehingga lesbian sulit mengaktualisasikan dirinya atau memodifikasi perilakunya sesuai dengan norma yang berlaku.

Hal ini menyebabkan terganggunya aspek sosial lesbian karena terbatasnya ruang gerak interaksi individu lesbian dengan keluarga, teman, dan lingkungannya. Keluarga cenderung menghukum lesbian dengan pengusiran, pengucilan, kekerasan fisik, dan sebagainya sehingga membuat lesbian semakin merasa tidak aman. Aspek moral akan dipertanyakan oleh masyarakat karena muculnya ketidaksesuaian norma masyarakat sehingga lesbian cenderung dianggap penyakit yang harus "diobati". Padahal sudah jelas bahwa lesbian bukanlah penyakit (dalam Pedoman Penggolongan dan Diagnosis Gangguan Jiwa III). Hal-hal tersebut akan memberatkan lesbian untuk berubah karena aspek psikis dirinya terganggu. Kebutuhan dasar fisiologis menjadi tidak terpenuhi dengan baik sehingga sulit untuk mencapai aktualisasi diri. Dan menjadi lesbian bukanlah bentuk perkembangan sosial yang diharapkan, karena dalam perkembangan sosial, manusia dituntut untuk memilih nilai-nilai sosial, mengembangkan hubungan sosial yang baik, dan tertarik kepada lawan jenis untuk selanjutnya menghasilkan keturunan. (Ali \& Ansori, 2006: 91).

Bagi kaum lesbian dengan masalah seksualitas dan gender yang melingkupinya, konsep diri akan sulit dibangun dengan kondisi lingkungan yang tidak mendukung. Padahal sebagai kesatuan sistem yang terintegrasi, lesbian tidak dapat dijauhkan dari kehidupan keluarga dan masyarakat. Pengaruh dari dalam diri dan lingkungan individu ikut menentukan konsep diri seseorang.

Pekerjaan sosial sebagai sebuah ilmu yang memiliki berbagai metode pemecahan masalah dan dalam praktiknya berfokus pada hubungan antarindividu, kelompok atau masyarakat dengan lingkungan sosial mereka, sangat tepat untuk membantu lesbian agar ia dapat menolong dirinya sendiri, termasuk terutama dalam mengenali konsep diri mereka. Kompetensi dan keterampilan pekerja sosial memungkinkan lesbian untuk membangun konsep diri yang positif serta membantu mereka memodifikasi atau merekonstruksi perilaku. Melalui pemahaman person in environment, lesbian tidak dipandang sebagai individu tunggal, namun bagian dari sistem yang holistik antara individu dengan lingkungannya. (Chazali, 2013 : 86)

Pekerja sosial memiliki peran yang penting dalam pembentukan konsep diri individu agar individu dapat menolong dirinya sendirinya dan meningkatkan keberfungsian sosialnya. Konsep diri yang baik dan positif dapat membantu individu untuk lebih percaya diri, bertanggung jawab, memiliki hubungan sosial yang baik, serta merubah atau meningkatkan sikap untuk lebih baik. Konsep diri menjadi dasar pembentukan fungsi sosial 
yang baik. Dalam proses pembentukan dan pemahaman konsep diri, terutama bagi lesbian, pekerja sosial dapat bergerak dalam social case work untuk pengembangan diri, baik dalam meningkatkan aspek sosial, aspek moral, aspek fisik dan aspek psikologis individu.

Tidak hanya melalui pendekatan metode social case work, pekerja sosial memiliki metode social group work dengan menggunakan kelompok sebagai perantara cara mengembangan diri dan peningkatan kemampuan untuk melaksanakan fungsi sosial. Peran pekerja sosial berbeda dengan psikolog. Pekerja sosial meletakkan pusat perhatiannya pada kemampuan orang untuk melaksanakan fungsi sosialnya. Intervensi tidak hanya dilakukan pada lesbian secara individu, namun juga memperhatikan aspek sosial dan hubungan individu dengan lingkungannya. Konsep diri tidak dibangun sendiri oleh individu, namun juga dipengaruhi oleh lingkungan sekitar. Sumber-sumber di lingkungan dapat dimanfaatkan untuk proses pembentukan konsep diri yang positif. Dan pekerja sosial memiliki peranan untuk menghubungkan individu dengan sumbersumber di lingkungannya.

Dengan demikian, konsep diri yang positif perlu dibangun tidak hanya oleh individu, namun diperlukan hubungan yang baik dan kondusif dengan orang-orang disekitarnya. Karena setiap lingkungan penuh dengan sumber-sumber yang membantu individu untuk terus bergerak menuju perubahan. Dan setiap individu, termasuk lesbian adalah sama, memiliki peluang untuk meningkatkan kapasitasnya untuk berkembang dan berubah. Sehingga, proses pemberian bantuan bukan pada pemberian solusi, namun intervensi pada interaksi, fungsi sosial, potensi dan sumber-sumber di lingkungan. Pada akhirnya, diri sendiri dan lingkungan yang membantu lesbian mengenali, menggali dan membangun konsep diri yang positif sehingga lesbian dapat berinteraksi dengan baik, berperan sosial dengan baik, puas dengan keadaan diri sendiri dan memungkinkan tumbuhnya kemauan untuk memodifikasi perilaku yang muncul dari dalam diri lesbian untuk kembali ke kodratnya. Sehubungan dengan hal tersebut, maka sangat penting untuk dilakukan penelitian atau kajian mengenai "Peran Pekerja Sosial dalam Pembentukan Konsep Diri Positif Bagi Lesbian".

Perumusan masalahnya adalah sebagai berikut : "Bagaimana peran pekerja sosial dapat berpengaruh terhadap pembentukan konsep diri positif bagi lesbian dalam proses perubahan perilaku?"

\section{PEMBAHASAN}

Keberadaan lesbian di Indonesia sudah menyebar hampir ke seluruh wilayah. Tidak hanya di kota-kota besar seperti Jakarta, Bandung dan Surabaya, di kota-kota kecil yang masih erat dengan budaya dan adat istiadat pun lesbian sudah mulai menunjukkan eksistensinya. Hal ini ditunjukkan oleh Kota Tasikmalaya sebagai salah satu kota santri yang terkenal sebagai tempat memperdalam ilmu agama. Dibalik hingar bingar pembangunan pesantren yang semakin canggih dan berteknologi, komunitas lesbian semakin eksis di kalangan masyarakat. Bahkan tidak jarang lesbian - lesbian di Kota Tasik berkumpul bersama dan mengadakan acara. Berdasarkan hasil observasi, tempat yang sering menjadi berkumpulnya lesbian berada di Kompleks Dadaha (Sport Center Kota Tasik).

Lesbian adalah perilaku seksual sesama jenis antar wanita. Lesbian termasuk kedalam jenis orientasi seksual. Orientasi seksual juga terbagi kedalam beberapa golongan. Pertama yaitu golongan homoseksual, merupakan ketertarikan terhadap sesama jenis; kedua adalah heteroseksual, yaitu tertarik dengan jenis kelamin yang berbeda; ketiga adalah biseksual, yaitu tertarik dengan kedua jenis kelamin. Orang-orang yang dianggap homoseksual disebut gay (laki-laki) dan lesbian (perempuan). Lesbian adalah istilah perempuan yang mengarahkan orientasi 
seksualnya kepada sesama perempuan atau disebut juga perempuan yang mencintai perempuan baik secara fisik, seksual, emosional atau secara spiritual. Lesbian juga adalah seorang perempuan yang memiliki ikatan emosional-erotis dan seksual terutama dengan perempuan atau yang melihat dirinya terutama sebagai bagian dari sebuah komunitas yang mengidentifikasikan diri lesbian. (Adhiati dalam Ary Trisna, $2010: 3$ )

Dengan demikian, lesbian tidak hanya merupakan masalah seksualitas, namun juga konsep diri dan pengaruh emosional. Namun norma-norma dan nilai-nilai di masyarakat hanya menerima heteroseksual, sehingga menjadi lesbian adalah bentuk ketimpangan. Lesbian terpolarisasi menjadi beberapa kelompok, baik menjadi kelompok feminis saja, kelompok lesbian saja, kelompok perempuan biasa saja, atau bahkan hanya menjadi kelompok lesbian yang mengasingkan diri dari masyarakat dan mempunyai kehidupan yang tertutup (atau yang disebut dengan the lesbian in the closet) (Brooks dalam Ary Trisna, 2010 : 4). Di Kota Tasik, jenis lesbian seperti ini memungkinkan keberadaannya. Hal ini karena ada pengaruh globalisasi yang semakin terbuka sehingga kelompok lesbian semakin tumbuh. Ada pula yang masih malu mengungkapkan dirinya lesbian, karena pengaruh agama dan budaya di Kota Tasik masih kuat.

Bagi perempuan, menjadi homoseksual bisa diakibatkan pula oleh perasaan nyaman terhadap sesama jenis, perasaan sakit di masa lalu oleh lawan jenis, dan terbawa arus pertemanan. Dalam prosesnya, lesbian biasanya diperankan oleh pasangan wanita dengan penampilan tomboy dan perempuan dengan sisi feminimnya (Astry Budiarti, 2011 : 3). Pembagian peran pada lesbian dibagi menjadi butch, wanita dengan fisik maskulin atau menyerupai pria, perannya mirip dengan laki-laki dalam hubungan heteroksual, femme adalah wanita yang secara fisik tidak berbeda dengan wanita pada umumnya, tampil feminim dan berperan sebagai "wanita" dalam hubungan lesbian dan andro, yaitu peran ganda (dapat menjadi pria ataupun wanita tergantung posisi yang diinginkan). Peran seperti ini juga berlaku di Kota Tasik. Butchy dapat diketahui lebih mudah dengan melihat tampilan fisik. Biasanya butchy menggunakan tampilan jeans, kaos/kemeja, dengan potongan rambut seperti laki-laki. Sedangkan femme masih sulit diidentifikasi karena secara fisik mirip dengan perempuan biasanya.

Jumlah lesbian di Kota Tasik diperkirakan mencapai sekitar 150 orang. Hal ini berdasarkan pengakuan salah seorang wanita yang tergabung dalam komunitas lesbian. Dari jumlah tersebut, kelompok lesbian ini sebagian besar berasal dari kalangan menengah ke bawah dengan usia belasan tahun. Namun tidak sedikit juga yang berasal dari kalangan berada. Bahkan sebagian besar mereka masih berstatus pelajar dan mahasiswa, selebihnya sudah tidak sekolah. Menariknya lagi, ternyata ada juga yang berstatus PNS dan karyawan BUMN. Menurut catatan Komisi Pemerhati Anak dan Remaja (KPAR) Tasikmalaya, jumlah warga terindikasi suka sesama jenis di Kota Santri pada 2014 adalah 1.578. Jumlah ini naik 300 orang dari tahun 2013, dan golongan ini tersebar di 69 kelurahan wilayah Kota Tasikmalaya.

Menurut penuturan penelitian lainnya mengenai lesbian di Kota Tasik, lesbian Tasik lebih memilih sembunyi-sembunyi menjadi kaum lesbian, mengingat saat ini masyarakat masih banyak yang belum menerima keberadaan kaum lesbian. Masyarakat masih menganggap lesbian sebagai penyakit yang harus disembuhkan. Akibatnya, banyak dari mereka yang memilih untuk menutup diri di tengah masyarakat, takut dikucilkan dari pergaulan.

Masyarakat Kota Tasik mengakui bahwa homoseksual sudah berkembang pesat di kota nya. Meskipun begitu, masyarakat masih menganggap permasalahan homoseksual sebagai hal yang tabu dan diharamkan oleh agama. Oleh karena itu, masyarakat yang mengetahui akan adanya lesbian cenderung "mengobati" lesbian 
tersebut dengan dimasukkan ke pesantren untuk mendapat dukungan spiritual. Ada pula yang mengusir dan mencela lesbian. Akibatnya, lesbian tidak memperoleh dukungan sosial dan tempat tinggal sehingga memilih untuk bergabung bersama komunitas lesbian yang dapat menerimanya dengan senang hati.

Paradigma pandangan seperti ini perlu diluruskan, karena lesbian bukanlah penyakit yang dapat diobati. Lesbian adalah perilaku seksual menyimpang. Artinya, proses "pengobatan" pun harus berfokus pada modifikasi perilaku. Dan penerimaan yang rendah terhadap lesbian tidak akan mengatasi masalah. Penerimaan diri berhubungan dengan konsep diri. Penerimaan diri yang rendah hanya akan membuat lesbian semakin terbelakang dan tidak percaya diri.

Berhubungan dengan konsep diri, ialah pemahaman pribadi seseorang mengenai kondisi dirinya yang dilihat melalui sudut pandang diri sendiri maupun orang lain. Konsep diri seseorang memperlihatkan bagaimana seseorang memiliki persepsi untuk menggambarkan diri dalam kehidupan yang akan membantu seseorang mencapai aktualisasi diri. Konsep diri adalah suatu gambaran campuran dari apa yang kita pikirkan terhadap pikiran orang lain mengenai diri kita dan seperti apa kita menginginkan diri kita (Burns, 1979). Konsep diri adalah salah satu unsur dalam kepribadian yang menerangkan perilaku. Konsep diri adalah bagaimana individu mengenal dirinya sendiri. Diri yang dikenal merupakan berbagai hal yang di persepsikan oleh individu tersebut, berupa konsep-konsep dan evaluasi mengenai diri sendiri juga termasuk gambaran gambaran dari orang lain terhadap dirinya yang dirasakan dan digambarkan sebagai pribadi yang diinginkan, yang dipelihara dari suatu pengalaman lingkungan yang dievaluasinya secara pribadi. (Burns, 1979)

Konsep diri ini menjadi penentu yang paling penting dari respon terhadap lingkungan. Konsep diri menunjang seseorang untuk bertingkah laku, berpikir, dan berinteraksi dengan orang lain. Bagaimana seseorang memandang dirinya akan menjadi cermin bagi dirinya maupun orang lain untuk memperoleh dan memenuhi kebutuhannya dengan baik. Burns (1979) menyatakan bahwa konsep diri yang positif dapat diketahui dengan adanya self esteem (penghargaan diri) yang tinggi. Sebaliknya konsep diri yang negatif dapat diketahui dengan evaluasi diri yang negatif, rasa benci terhadap diri, merasa rendah diri, kurang dapat menerima dan merasa kurang berharga. Oleh karena itu, konsep diri positif akan membawa seseorang dalam keberhasilan dan kesuksesan, sedangkan konsep diri negatif akan menjauhkan seseorang dari kesuksesan.

Dengan demikian konsep diri adalah cara pandang, cara berpikir dan berperasaan tentang bagaimana kita memandang diri sendiri, bagaimana kita berpikir terhadap diri sendiri dan bagaimana kita merasakan diri sendiri sebagai manusia yang kita inginkan disertai pandangan orang lain terhadap diri kita. Bagi kelompok minoritas, seperti lesbian, konsep diri mereka didorong oleh pandangan diri sendiri terhadap perilaku seksual yang dianggap menyimpang oleh nilai dan norma di masyarakat, serta pandangan orang lain yang masih menganggap lesbian adalah penyakit jiwa, membuat lesbian sulit mengkonsepkan dirinya positif. Padahal konsep diri penting dalam membentuk diri ideal dan perkembangan diri untuk meraih aktualisasi diri. Namun self esteem atau penghargaan diri lesbian sering tidak terpenuhi sehingga yang terjadi adalah konsep diri negatif yang dibangun. Pembentukan konsep diri positif bagi lesbian terutama remaja, akan menentukan bagaimana diri mereka di masa depan. Nilai moral, agama, dan sosial akan menghambat keputusan mereka untuk tetap menjadi lesbian, sehingga lesbian membutuhkan konsep diri yang akan membantu mereka mengenal diri mereka sendiri, memahami kebutuhan dan masalah mereka sendiri, sehingga mereka dapat membantu diri mereka dalam menangani masalahnya. 
Menurut Brooks \& Emmert (Brooks dan Emmert dalam Desmita 2009 : 28) ada dua macam konsep diri yaitu:

a) Konsep diri positif memiliki ciri-ciri:

1) Yakin akan kemampuannya menyelesaikan masalah.

2) Merasa setara dengan orang lain.

3) Menerima pujian tanpa rasa malu.

4) Menyadari bahwa setiap orang mempunyai berbagai perasaan, keinginan dan perilaku yang tidak seluruhnya disetujui masyarakat.

5) Mampu memperbaiki dirinya karena sanggup mengungkapkan aspek kepribadian yang tidak disenangi dan ingin berubah.

b) Konsep diri negatif memiliki ciri-ciri:

1) Sangat peka terhadap kritik. Orang yang memiliki konsep diri negatif sangat tidak senang terhadap kritik yang ditujukan kepadanya sehingga ia akan mudah marah atau naik pitam apabila dikritik. Bagi orang yang memiliki sikap seperti ini koreksi sering kali dipersepsi dengan usaha untuk menjatuhkan harga dirinya.

2) Responsif terhadap pujian. Orang yang memiliki konsep diri negatif akan merasa sangat senang terhadap segala macam pujian yang ditujukan kepadanya. Sehingga segala bentuk pujian dan tindakan yang menjunjung harga diri akan menjadi perhatian utamanya.

3) Bersikap hipokratis. Sebagai konsekuensi dari sikap yang kedua di atas, orang ini akan bersikap hipokratis terhadap orang lain. Ia akan selalu mengeluh dan merendahkan apapun dan siapapun orang itu.

4) Merasa cemas. Orang yang memiliki konsep diri negatif akan selalu merasa cemas karena ia selalu merasa dirinya tidak disenangi oleh orang lain. Ia merasa tidak diperhatikan sehingga ia cenderung bereaksi terhadap orang lain sebagai musuh. Ia tidak mempersalahkan dirinya tapi ia akan menganggap dirinya sebagai korban dari sistem sosial yang berlaku.

5) Bersikap pesimis terhadap kompetisi. Orang yang memiliki konsep diri negatif akan bersikap pesimis terhadap kompetisi dan akan selalu berusaha untuk menghindari kompetisi yang dianggap dapat menjatuhkan harga dirinya. Hal ini terungkap dari keengganannya untuk bersaing dengan orang lain dalam membuat prestasi.

Konsep diri positif membantu individu untuk bergaul dengan baik, menjadi diri apa adanya, memahami apa yang diinginkan dan harus dilakuka, sehingga individu terbantu dalam menjalankan kehidupannya. Konsep diri positif menjadi tolak ukur keberhasilan seserorang dengan pemahaman yang baik mengenai diri sendiri, tidak ragu dalam mengambil keputusan, berani dalam bertindak dan sesuai rasional, menggunakan pandangan positif terhadap segala hal yang akan meningkatkan motivasi sehingga individu mencapai aktualisasi dirinya. Berbanding terbalik dengan konsep diri negatif, sulit melangkah ke depan karena terlalu banyak kekhawatiran dan ketakutan, tidak percaya diri, tidak memiliki semangat juang untuk mencapai tujuan yang diharapkan.

Selain itu, terdapat aspek-aspek dalam konsep diri menurut Berzonsky, diantaranya :

1) Aspek fisik, yaitu bagaimana penilaian individu terhadap segala sesuatu bayang terlihat secara fisik yang dimilikinya seperti tubuh, kesehatan, pakaian penampilan. 
2) Aspek sosial, yaitu bagaimana peranan sosial yang perankan individu mencakup hubungan antara individu dengan keluarga dan individu dengan lingkungan.

3) Aspek moral, merupakan nilai dan prinsip yang memberi arti dan arah dalam kehidupan individu dan memandang nilai etika moral dirinya seperti kejujuran, tanggungjawab atas kegagalan yang dialaminya, religiusitas serta perilakunya. Apakah perilaku dalam menjaga kebersihan organ reproduksi sesuai dengan norma yang ada dan tidak mengganggu kepentingan masyarakat sekitar.

4) Aspek psikis, meliputi pikiran, perasaan dan sikap yang dimiliki individu terhadap dirinya sendiri. (http://digilib.unila.ac.id/2888/13/BAB \%20II.pdf diakses pada tanggal 5 April 2015 pukul 20.06)

Dengan demikian, aspek-aspek konsep diri akan membangun konsep diri manusia seutuhnya. Dapat disimpulkan bahwa aspek konsep diri dapat dibagi menjadi empat aspek, yaitu aspek fisik, aspek psikologis, aspek diri ideal, dan aspek sosial. Aspek fisik merupakan pandangan individu mengenai berbagai hal yang dapat dilihat, mulai dari penampilan, perilaku, jenis kelamin, tubuh, dan hal lainnya yang menjadi daya tarik individu terhadap lingkungannya. Aspek psikologis adalah keadaan perasaan dan pikiran individu terhadap dirinya sendiri, seperti kemampuan, kepercayaan, tanggung jawab, kewajiban, harga diri, dan moral yang dimiliki oleh individu dalam dirinya sendiri. Aspek diri ideal adalah keinginan atau harapan individu untuk berkembang di masa depan, menjadi seperti apa dan siapa, serta bagaimana langkahlangkah yang perlu dilakukan untuk menjadi sosok ideal tersebut. Aspek terakhir adalah aspek sosial, aspek ini menekankan pada bagaimana orang lain dan lingkungan memandang dan menilai individu, peran dan status individu dalam lingkungan, serta hubungan interaksi yang dijalankan individu dengan lingkungannya. Aspek-aspek tersebut diperlukan dalam membangun konsep diri karena konsep diri bukanlah gagasan yang dibuat oleh individu itu sendiri sehingga bukan aturan pribadi, namun pemahaman diri dari aspek diri sendiri maupun orang lain yang membentuknya. Karena manusia adalah makhluk sosial, maka konsep diri adalah tanggung jawab sosial, bukan hanya satu individu namun dilihat secara holistik

Pertumbuhan lesbian yang semakin tidak terkendali di Kota Tasik dapat diidentifikasi dan di assessment dengan melihat bagaimana konsep diri yang dibangun kepada masyarakat. Bagaimana karakteristik masyarakat dan pengaruh kebijakan pemerintah dalam mengendalikan lesbianisme. Dimanakah letak simpul utama yang menjadi akar permasalahan maraknya lesbian dan apakah pemerintah sudah aware terhadap masalah lesbian. Peraturan Daerah Kota Tasikmalaya No. 12 Tahun 2009 tentang "Pembangunan Tata Nilai Kehidupan Kemasyarakatan Yang Berlandaskan Pada Ajaran Agama Islam Dan Norma-Norma Sosial Masyarakat Kota Tasikmalaya" telah menjadi jawaban bahwa pemerintah Kota Tasikmalaya sudah memperhatikan permasalahan homoseksual yang tertuang dalam Pasal 5 ayat 3 dan 4 yang berbunyi "Setiap muslim wajib mencegah dan menghindari perbuatan-perbuatan dan tindakan-tindakan tercela yang dapat menimbulkan kerugian dan keruntuhan akhlaq, moral dan sosial." Tindakan yang dimaksud salah satunya adalah homoseksual. Pada Pasal 9 ayat 3 juga dinyatakan bahwa pemerintah bertanggung jawab dalam pencegahan melalui kegiatan penyuluhan, pendidikan formal dan informal serta kegiatan lainnya. Kebijakan ini seharusnya mampu menjadi pedoman bagi pemerintah dan pihak terkait dalam mengatasi permasalahan lesbian. Penyuluhan menjadi langkah preventif dalam peningkatan moral masyarakat. Pendidikan formal dan informal juga seharusnya dapat menjadi langkah strategis dalam mengurangi 
lesbianisme di Kota Tasik. Pemberian pengetahuan dan peningkatan keterampilan adalah salah satu upaya dalam proses pembentukan konsep diri yang positif. Dan konsep diri positif dapat mempengaruhi perilaku individu untuk berubah. Sehingga, lesbian yang memiliki konsep diri positif memiliki kesempatan besar untuk berubah menjadi normal. Sayangnya, langkah pemerintah masih belum kuat sehingga lesbian masih bertambah setiap tahunnya.

Diperlukan langkah-langkah lain dalam upaya perubahan orientasi lesbian melalui pembentukan konsep diri yang positif. Pekerja sosial adalah profesi pemberian bantuan yang bersifat profesional. Pekerja sosial memiliki empat peran dalam membantu kliennya, diantaranya :

1. Meningkatkan kapasitas orang dalam mengatasi masalah yang dihadapinya. Pekerja sosial mengidentifikasi hambatanhambatan klien dalam melaksanakan tugas-tugas kehidupannya. Lesbian seringkali dipandang sebagai individu yang tidak mampu dan tidak bertanggung jawab sehingga lesbian jarang diberikan kepercayaan untuk meningkatkan kemampuannya. Pekerja sosial dapat membantu lesbian untuk menggali kekuatan yang dimilikinya untuk dikembangkan sehingga lesbian memperoleh kepercayaan dari orang lain. Hal ini berkaitan dengan aspek psikis individu. Pemikiran dan perasaan individu akan terbuka dengan meningkatnya kemampuan dan kepercayaan diri sehingga lesbian merasa dirinya lebih dihargai dan mau untuk membuka diri serta menerima sugesti.

2. Menggali dan menghubungkan sumbersumber yang tersedia di sekitar klien. Peran ini menggunakan PIE (Person In Environtment) yang memandang manusia utuh sebagai bagian dari sistem lingkungan, dan bagaimana interaksinya. Minihan (1981) menulis bahwa dalam melaksanakan tujuannya, pekerja sosial meningkatkan atau mengembalikan, memfasilitasi interaksi timbal-balik yang saling menguntungkan antara individu dan masyarakat dan membantu manusia meningkatkan kompetensi dan kemampuannya dalam menangani dan mengatasi masalah. Menjadi lesbian tidak datang secara naluriah, ada pengaruh lingkungan dan orang di sekitar yang membuat seseorang memutuskan menjadi lesbian. Konsep diri juga dipengaruhi oleh lingkungan. Bagaimana orang lain memandang individu secara fisik dan penampilan, secara sosial melalui hubungan dengan orang lain, dan aspek moral yang menghubungkan lesbian dengan Tuhan dan nilai serta norma, merupakan sumber-sumber lingkungan. Jika pekerja sosial mampu menggali dan menghubungkan lesbian dengan sumber di lingkungan melalui pendekatan PIE, makalesbian dapat mengenali konsep dirinya dan menggunakan sumber lingkungan untuk proses modifikasi perilaku. Karena lingkungan mampu mempengaruhi lesbian untuk berubah.

3. Meningkatkan jaringan pelayanan sosial. Pekerja sosial berperan untuk menjamin kesejahteraan sosial berjalan secara manusiawi, sensitif terhadap kebutuhan warga setempat dan efektif dalam memberikan pelayanan sosial terhadao masyarakat. Meskipun yang menjadi klien adalah lesbian, namun proses intervensi tidak hanya melibatkan lesbian. Pekerja sosial juga melakukan intervensi terhadap keluarga lesbian, masyarakat sekitar dan pihak-pihak yang berkaitan. Pekerja sosial juga perlu mendengarkan aspirasi dan pandangan masyarakat terhadap permasalahan lesbian. Hal ini diperlukan untuk proses intervensi yang holistik agar terciptanya kedamaian yang diharapkan semua orang.

4. Mengoptimalkan keadilan sosial melalui pengembangan kebijakan sosial. Pekerja sosial membuat naskah kebijakan yang memuat rekomendasi-rekomendasi bagi pengembangan kebijakan-kebijakan baru 
maupun perbaikan atau pergantian kebijakan-kebijakan lama yang tidak berjalan efektif. Pekerja sosial juga dapat menterjemahkan kebijakan-kebijakan publik ke dalam program dan pelayanan sosial yang dibutuhkan. Kebijakan yang dibuat oleh Pemda Tasik belum mampu mengatasi permasalahan lesbian. Pekerja sosial dapat memuat rekomendasi untuk pengendalian lesbian dengan cara yang berbeda. Seperti menggunakan social case work dengan upaya pengembangan diri. Pengembangan diri dapat dilaksanakan di instansi atau lembaga sosial dengan bantuan guru, motivator, dan pekerja sosial sendiri. Lalu menggunakan pendekatan social group work. Pendekatan ini lebih mudah dan efektif karena individu mampu mengembangkan diri dan merasa diterima didalam kelompok. Kelompok dapat berisi lesbian saja, maupun lesbian-keluargamasyarakat. Di dalam kelompok, pekerja sosial hanya menjadi fasilitator yang menjaga jalannya kegiatan. Keseluruhan isi diskusi dikembalikan pada anggota dan pekerja sosial membebaskan setiap orang untuk berpendapat tanpa menyakiti perasan orang lain. Bagi lesbian, dapat menggunakan treatment group yang berupa remedial group maupun socialization group. Remedial group untuk kelompok terapi bagi klien yang ingin mengubah perilaku. Sedangkan socialization group adalah kelompok yang membantu partisipan dalam menjadikan kebutuhan akan keterampilan menjadi hal yang tersosialisasikan di masyarakat. Socialization group sangat tepat bagi pengembangan kelompok dimana anggotanya pernah menjadi bagian dalam masalah sosial. Selain itu, pekerja sosial dapat bergerak dalam bidang pelayanan sosial terutama memberikan konseling bagi lesbian. Karena lesbian adalah kelompok marginal yang menyimpang norma dan nilai-nilai masyarakat Indonesia, lesbian seringkali tidak memperoleh keadilan dan tempat bernaung. Dengan adanya kebijakan dari Perda No. 12 Tahun 2009, pekerja sosial dapat memanfaatkan kebijakan tersebut sebagai peluang dalam pemberian pelayanan sosial. Masih lemahnya produk hukum tertulis harus diperkuat oleh program yang benar-benar dilakukan oleh profesional sebagai upaya memperbaiki sistem dan menciptakan kesejahteraan sosial. Oleh karena itu, meskipun lesbian adalah individu, namun permasalahan ini juga melibatkan peran orang tua, teman, dan masyarakat secara luas. Karena ketidaknyamanan masyarakat akan menimbulkan masalah sosial lainnya.

Selain pekerja sosial, sudah menjadi tugas dan tanggung jawab stakeholder lain dalam upaya penanganan masalah lesbian. Stakeholder ini dapat menjadi rekan pekerja sosial dalam menjalankan prakteknya. Mengenai upaya menangani permasalahan lesbian, pekerja sosial dapat bekerja sama dengan MUI regional Tasik dan tokoh masyarakat sebagai rekan dalam usaha peningkatan aspek moral, bersama dengan dinas sosial, dinas pendidikan, dan BKKBN melakukan upaya preventif dan promotif untuk mensosialisasikan bahaya lesbian dari sisi pengetahuan, faktor-faktor yang menyebabkan, dan kesulitan yang akan dihadapi serta membangun mental dan psikis individu untuk tidak mudah terjemurus. Bersama masyarakat dan LSM terkait seperti KPAR (Komisi Perlindungan Anak dan Remaja), pekerja sosial membantu lesbian dalam hal penerimaan diri, penghargaan diri, peningkatan keterampilan, konseling, group work, menggali kekuatan dan sumber-sumber di lingkungan, yang dapat membangun konsep diri positif bagi lesbian. Untuk selanjutnya, lesbian dapat mengubah dirinya sendiri tanpa ada paksaan dan atas keinginan dari dalam diri. 
Tabel 1 ini menunjukkan stakeholder yang dapat diajak bekerjasama.

\begin{tabular}{|l|l|l|}
\hline NO & INSTANSI & JENIS LAYANAN \\
\hline & SKPD/OPD & Upaya preventif dan promotif \\
\hline 1 & Dinas Sosial & Sosialisasi dan pendidikan seksual \\
\hline 2 & Dinas Pendidikan & Upaya preventif dan promotif \\
\hline 3 & BKKBN & Peningkatan moral \\
\hline 4 & MUI dan pesantren & Perlindungan dan Konseling \\
\hline 5 & KPAR & $\begin{array}{l}\text { Pemberian Komunikasi Informasi dan } \\
\text { Edukasi(KIE) Serta Komunikasi } \\
\text { Perubahan Perilaku (Behaviour } \\
\text { Change Communication / BCC) }\end{array}$ \\
\hline 1 & NGO dalam negeri \\
\hline
\end{tabular}

Sampai saat ini, keterlibatan stakeholder belum sepenuhnya berjalan sehingga kebijakan yang telah ada belum optimal. Keterlibatan stakeholder dalam penanganan lesbian di Kota Tasik belum terkoordinasi dengan baik dan belum didukung oleh keberadaan pekerja sosial professional yang cukup memadai secara kuantitas.

\section{SIMPULAN DAN SARAN}

Proses pembentukan konsep diri positif bagi lesbian bertujuan agar lesbian mampu meningkatkan kemampuan dan fungsi sosial, menyadari bahwa setiap orang mempunyai berbagai perasaan, keinginan dan perilaku yang tidak seluruhnya disetujui masyarakat serta mampu memperbaiki dirinya karena sanggup mengungkapkan aspek kepribadian yang tidak disenangi dan ingin berubah. Pekerja sosial memiliki peran yang penting dalam upaya pembentukan konsep diri positif bagi lesbian. Dengan menggunakan pemahaman PIE (person in environtment), lesbian tidak dipandang sebagai individu tunggal namun bagian dari sistem sosial yang lebih kompleks. Lesbian adalah individu, bagian dari keluarga, hubungan pertemanan, organisasi dan masyarakat. Pekerja sosial melakukan assessment tidak hanya berdasarkan pada individu, namun melakukan intervensi pada bagian dari individu, seperti keluarga, teman dan masyarakat yang berhubungan dengan individu. Hal ini dimaksudkan karena PIE berhubungan dengan proses pembentukan konsep diri. Konsep diri adalah gambaran seseorang terhadap dirinya sendiri yang diperoleh dari penilaian diri dan penilaian orang lain. Konsep diri tidak dibentuk secara naluriah oleh individu, namun dipengaruhi oleh lingkungan dan pandangan orang lain.

Untuk membentuk konsep diri yang positif, perlu memperhatikan bagaimana situasi dan kondisi lingkungan, nilai dan norma serta karakteristik lingkungan. Aspek konsep diri sendiri terdiri dari aspek fisik, aspek sosial, aspek moral, dan aspek psikis. Aspek fisik adalah pandangan individu mengenai penampilan fisik dirinya, seperti tubuh, gaya berpakaian, sikap. Aspek sosial berkaitan dengan hubungan individu dengan sekitarnya. Aspek sosial dilihat dan dinilai oleh orang lain, hubungan sosial yang baik akan membuat aspek sosial yang baik. Aspek moral berkaitan dengan dalam diri individu dan nilai serta 
norma yang menjadi aturan masyarakat. Aspek moral juga menyangkut hubungan individu dengan Tuhan. Aspek psikis berkaitan dengan pikiran, perasaan dan pendapat yang dimiliki individu. Keempat aspek tersebut jika berhasil maka akan menciptakan konsep diri positif.

Pekerja sosial adalah profesi pemberian bantuan yang dapat membantu mengembangkan konsep diri positif bagi lesbian guna peningkatan fungsi sosial maupun mengembangkan sumber-sumber individu. Dengan menggunakan metode social case work, social group work, sampai organisasi pelayanan manusia, pekerja sosial menjadi profesi profesional yang dapat mengatasi permasalahan lesbian di Kota Tasik. Pekerja sosial juga dapat mengembangkan kebijakan Perda Tasik No. 12 Tahun 2009 menjadi program yang bergerak di bidang seksualitas bekerjasama dengan stakeholder terkait.

Beberapa rekomendasi atau saran untuk menangani permasalahan lesbian di Kota Tasik diantaranya :

1. Pengembangan diri masyarakat melalui program pemberdayaan remaja.

2. Perlu adanya kebijakan khusus yang mengatur mengenai penanganan masalah homoseksual. Pemerintah Tasikmalaya perlu memberikan perhatian khusus mengenai permasalahan ini, tidak hanya menganggap lesbian sebagai perbuatan tercela yang menyimpang dari aturan agama dan norma, namun menggunakan perspektif lain dalam proses penanganannya. Misal, edukasi mengenai seksualitas dan mencoba masuk kedalam komunitas-komunitas lesbian untuk mendengar permasalahan mereka sehingga intervensi yang dilakukan pemerintah tidak salah sasaran.

3. Perlu adanya kerjasama antara pemerintah, LSM, dinas-dinas, masyarakat, dan profesi profesional untuk merumuskan program yang tepat dalam upaya penanganan masalah lesbian.

4. Perlu adanya pekerja sosial profesional yang membantu pembentukan konsep diri positif bagi lesbian agar lesbian mampu memodifikasi perilakunya.

\section{DAFTAR PUSTAKA}

Albert R Roberts and Gilbert J. 2009. Buku Pintar Pekerja Sosial Jilid 2. Jakarta : BPK Gunung Mulia.

Astry Budiarty. 2011. Skripsi berjudul "Gaya Hidup Lesbian (Studi Kasus di Kota Makassar)". Universitas Hasanuddin.

Budhi Wibhawa, dkk. 2010. Dasar-dasar Pekerjaan Sosial. Bandung : Widya Padjadjaran.

Laily Andini. 2013. "Maraknya Fenomena Lesbian dan Gay di Indonesia". Melalui http://kesehatan.kompasiana.com/kejiwaa n/2013/12/24/maraknya-fenomenalesbian-dan-gay-di-indonesia619262.html [2015/03/24]

Pew Research Center. 2013. The Global Divide on Homosexuality Greater Acceptance in More Secular and Affluent Countries.

R. B. Burns. 1979. Self Concept : Theory, measurement, development, and behaviour. USA : Longman Inc.

Tugu Muda. (tanpa tahun). "Konsep Diri Seorang Remaja". Melalui https://www.academia.edu/3778904/Kon sep_Diri_Seorang_Remaja [2015/03/28]

(tanpa nama). (tanpa tahun). Melalui http://digilib.unila.ac.id/ 2888/13/ BAB\%20II.pdf [2015/04/08]

(tanpa nama). 2015. Melalui http://www.radartasikmalaya.com/ kabupaten/ tasikmalaya/2015/1-578-gaytersebar-di-tasik.html [2015/05/10] 